\title{
THE TELEVISION BUSINESS IN INDONESIA: A COMPARATIVE STUDY OF THE OLD REGIME, THE NEW ORDER, AND THE REFORM ERA
}

\section{Rendra Widyatama}

Károly Ihrig Doctoral School of Management and Business, University of Debrecen, Debrecen, Hungary, and Communication Department, Faculty of Literature, Culture, and Communication, University of Ahmad Dahlan, Yogyakarta, Indonesia rendrawidyatama@gmail.com

\begin{abstract}
This article compares the television industry in Indonesia during the reign of the Old Order, the New Order, and the Reform Era. A full review of television broadcasting in all eras is still rarely carried out by Indonesian researchers. The author uses qualitative research methods in the form of comparative studies and library studies based on secondary data. In this comparison, the author focuses on eleven aspects of the problem, namely; the system of broadcasting, ownership, the form of broadcasting institutions, objectives, funding, broadcast coverage, control, and supervision, licensing, press freedom, media content trends, and society in relation to the television industry. The author found that although since independence Indonesia has been based on Pancasila democracy, in every era of government there have been differences in TV broadcasting arrangements. The Old Order period was more dominated by the role of government. This situation continued during the first 20 years of the New Order government, but in the last ten years of the New Order, the private sector dominated the TV industry. This dominance has continued into the reform era and treats society as a market and a political object. During all periods, it is the government which determines to license, and the implementation of the Broadcasting Act is not strictly enforced. A less strict attitude in the implementation of the Broadcasting Act indicates that the country is flexible and endeavours to find ways to compromise with stakeholders.
\end{abstract}

Keywords: System broadcasting, Television broadcasting ownership, Decentralism, Broadcasting purpose, Funding of broadcasting

JEL Classification: K20, N00, P50

\section{Introduction}

Television has a very important strategic position in the community. In many countries, television is capable of generating substantial revenue for the state. As of 2015 the Chinese TV industry generates revenues of US $\$ 17.55$ billion (PWC, 2016), in India the figure is US\$ 22.1 billion (Global Forum on Competition, 2013), while in the United States it earns US\$ 1.19 trillion and occupies the most prominent position worldwide (Woods \& Poole Economics, 2015). In Indonesia, the TV industry earned US $\$ 5.4$ billion and has recently increased by $11 \%$ to US $\$ 6$ billion (Marketline, 2017).

The television industry also opens up millions of jobs. In the U.S.A, the television industry absorbed 1.47 million workers (Woods \& Poole Economics, 2015). In India, in 2016-2017 1.38 million people were employed (MIB, 2017), while in 2016, China's film and TV industry provided work for 1.1 million employees, of which $79 \%$ were in the television industry (Oxford Economics, 2016). In Indonesia, the number of workers absorbed in 2002-2006 was 142,227 (Pangestu, 2008). The number rose rapidly to 647,937 in 2010 (BPS, 2010).

The television business is part of the press system. Television broadcasting institutions do not work independently but are influenced by, and influence, different social systems and are 
determined by the political philosophy and policy of the government in which the media operate (Fischer, 1976). Even though they may be in the same democratic system, the regulation of the TV industry may vary from government to government because they have different interests in TV.

In Indonesia, every period of government has implemented regulations differently, albeit based on the same political system, i.e., Pancasila democracy. Pancasila democracy is a democracy based on the principle of consensus and community self-help. Society combines the universal aspirations of democracy with the ideals of Indonesian life inspired by the spirit of kinship, so there is no majority or minority domination. Based on the above description, the author raises the interesting question, what have been the differences in the TV industry during the various regimes in Indonesia?

Investigating Indonesia's broadcasting TV industry is interesting, for two main reasons. Firstly, there have not been many Indonesian researchers who have thoroughly explained the TV broadcasting industry by comparing each period of government. The literature on this subject is sketchy, so to understand the topic we need to read many studies. Secondly, information on the issue can illustrate the nature of the pattern of relationships between government and the private sector in the TV broadcasting industry.

\section{Methodology}

In this research, the author has a specific purpose of describing the Indonesian television business during the period of government between the Old Order, the New Order, and the Reform Era through comparative and literature studies. There are three stages to achieve the purpose of the study. The first stage is to collect all relevant literature as data sources in the form of documents related to TV business from an economic perspective. Documents related to this issue are not have enough attention from Indonesian researchers. Literature about TV more reveals the influence of TV on the aspects of the theory of uses and gratification and its impact on society.

The second stage is to devise the aspects used to study the research problem. The author uses 11 points were highlighted; namely, the broadcasting system, broadcasting ownership, the institutional categories of broadcasting, the purposes, the funding, broadcasting coverage, control and supervision, licensing authority, the freedom of the press, the trends of media content, and the position of viewers. The third stage is to analyze the television business in each period of government. The last step is to formulate conclusions and write a scientific article.

\section{Discussion}

Since independence in 1945, Indonesia has had three periods of government, namely the Old Order, the New Order, and the Reform Era. The Old Order was under the leadership of President Soekarno (1945 to 1968). After Soekarno fell from power, the New Order begins, lasting until 1998, with Soeharto as president. The New Order fell following a severe monetary crisis which developed into political unrest with demands for reform. The successor of the New Order is often referred to as the Reform Era.

\subsection{The Television Industry in the Old Order}

Television broadcasting was present in Indonesia in 1962 when the Old Order came to power. In this period, Soekarno initiated the establishment of a TV broadcasting station, named Televisi Republik Indonesia (TVRI). Initially, the goal of TVRI was to cover the sports of the IV Asian Games in Jakarta, enhancing Indonesia's image internationally (Alimuddin, 2017). TVRI became the personal interest of Soekarno. 
The Old Order established TVRI as the only TV station in Indonesia, and it declared this in Presidential Decree 215/1963 and used TVRI as a political medium. Article 4 of the Presidential Decree proclaimed that TVRI was an instrument of public relations in the implementation of mental/spiritual and physical development of the nation and state, especially in the formation of the Indonesian socialist human being. To ensure the achievement of these goals, TVRI was directly managed by the president and directors, assisted by specific officials for TVRI affairs.

As a state-owned channel, TVRI received a budget from the government, but the funding was not sufficient to finance TVRI operations, so the government allowed it to accept advertising. Article 8 of Presidential Decree 215/1963 named three sources of funding for TVRI, namely government subsidies, compulsory contributions from owners of television receivers, and revenue proceeds from TVRI activities, including advertising. Furthermore, the Old Order issued a presidential decree (No. 218 of 1963) including a requirement for the public to pay a license fee.

In 1964, the government pioneered the construction of seven public TV stations in the regions. All regional TV stations were relay stations but could produce their programming based on the central TVRI platform. The government-controlled broadcasting. Hence the television stations did not have much freedom, particularly after the government implemented a 'guided democracy' on July 1st, 1959. The content of television broadcasts was more oriented to the elites, especially the president. Society was more a political target (Panjaitan, 2006).

\subsection{Television Industry in the New Order}

The New Order lasted from 1966 to 1998, led by President Soeharto. In the first 23 years of the New Order, TVRI was still the only TV station in Indonesia. The granting of five private TV station licenses occurred in the last nine years of the New Order. Soeharto regarded TV as a highly strategic political medium for gaining public support, in addition to preserving the nation's ideology and reinforcing the concept of pluralistic Indonesian society. Formally, the government set three purposes for TVRI, namely promoting national unity, promoting domestic stability, and promoting political stability (Panjaitan, 2006).

On July $8^{\text {th }}, 1976$, the government bought the Palapa satellite to realize the vision of building community unity. Indonesia was the third nation after Canada and Russia to use domestic satellites for broadcast TV. Despite purchasing the spacecraft, the government continued to build gradually from 7 regional TVRI stations during the Old Order to 29 stations and 395 terrestrial network transmission stations scattered throughout Indonesia. But unfortunately, the broadcasting system was centralized and controlled from Jakarta. The New Order carried out strict supervision and censorship of the press.

In the New Order period, the government continued to subsidize TVRI, while permitting the company to accept TV advertising to cover the shortfall. However, from April $1^{\text {st }}$, 1981 , the government banned TVRI from receiving advertisements, although advertising revenue accounted for $51 \%$ of TVRI's budget (Armando, 2011). The prohibition of advertising makes TVRI funds drastically decreased. This situation caused TVRI to begin to lose its audience because it could not produce attractive programs to compete with private TV. In support of TVRI funds, in 1990 the government issued presidential decree No. 40, ordering society to pay license fees as in the Old Order, but this policy was opposed by the community at large. Hence the policy was failing.

In the 1980s, the Indonesian economy grew remarkably, boosting the middle class. They began to watch international TV shows via satellite antennas instead of watching monotonous TVRI broadcasts (Sen and Hill, 2006). Through a parabolic antenna, people could watch 6-20 international outstations. To control parabolic ownership, the Minister of Information issued the open sky policy. 
The increasing tendency to watch overseas TV was captured as a business opportunity by businessmen applying for a TV broadcasting license to keep people watching Indonesian TV broadcasts. Interestingly, the proposal was approved, and in 1987 the government issued decree no. 190A/KEP/MENPEN 1987, stating that TVRI had the right to carry public broadcasting (SSU) and limited broadcasting channels (SST). In SSU, people can catch TV signals without specific devices, while to watch SST special tools must be used. To organize SST, TVRI appointed the other party as the agent, under TVRI control. Advertising was allowed in SST, and profits were managed by TVRI to support TVRI operations. Surprisingly, the government granted licenses to Soeharto's family and cronies.

Rajawali Citra Televisi Indonesia (RCTI) was the first TV station to obtain an SST license. RCTI belongs to Bambang Trihatmodjo (second son of Soeharto). The collaboration agreement with TVRI began in 1989, for SST broadcasting in Jakarta and surrounding areas, with the agreement that $12.5 \%$ of the profits would be transferred to TVRI. In the first broadcast, RCTI gained 70,000 subscribers and increased by $92.86 \%$ in 1990 . The success of RCTI in Jakarta made Bambang apply for an SST license for the Bandung area.

Sudwikatmono, Soeharto's cousin, also applied for an SST license through Surya Citra Televisi (SCTV) for the Surabaya and Denpasar areas. Sudwikatmono collaborated with Henry Pribady, an influential individual in the Sudono Salim Group owned by Liem Sioe Liong, a business partner of the Soeharto family. Later, Halimah Trihatmojo (Bambang Trihatmodjo's wife), joined as one of SCTV's shareholders. SCTV was targeting the urban and upper middle class (Rakhmani, 2013).

The success of RCTI and SCTV prompted Siti Hardiati Indrarukmana (Mba Tutut), the eldest daughter of Soeharto to register Televisi Pendidikan Indonesia (TPI) as a TV channel but in an SSU format, and with promised educational programmes as the primary content. To realize its activities, Mba Tutut used TVRI facilities for both production and transmission. In particular, although SSU rights were only for TVRI, the government approved the TPI proposal. Later, TPI was sold to Harry Tanoesudibyo, and the new owner renamed it MNCTV and switch to a profit-seeking.

The license for TPI to broadcast free to air nationally was made by both RCTI and SCTV. In 1990 the state allowed RCTI and SCTV to be a Broadcast Station for Private Television (SPTSU), but the government requested that all stations have their headquarters in Jakarta. Finally, RCTI Bandung joined RCTI Jakarta; SCTV Surabaya and SCTV Denpasar merged into one company, headquartered in Jakarta.

Soeharto also gave licenses to his political and business cronies. On January $30^{\text {th }}, 1999$, the government issued a permit to ANTV, owned by Aburizal Bakrie in collaboration with Agung Laksono. This commercial TV station targeted young people in urban areas (Rakhmani, 2013). Among his business cronies, Soeharto granted a broadcast license to Lim Sioe Liong, to establish Indosiar Visual Mandiri (Indosiar). The company targeted middle and upper-class audiences in urban areas.

In 1997, the New Order published Act no. 24/1997 on broadcasting, to organize the TV industry. Article 16 of this Act affirmed the centralized system of TV broadcasting which required all TV stations to be in the capital city. According to the Broadcasting Act, there were three forms of broadcasting institutions, namely state broadcasting, private TV broadcasting, and special broadcasting. State broadcasting was owned and financed by the government. Special TV broadcasting included cable TV, subscription TV, closed-circuit TV, video-on-demand services; audio text services; videotext services; multimedia information service, etc. The share of TV broadcasting ownership by the president's family and cronies meant that commercial TV stations did not function as a media control over the government. The New Order had a strong position on the licenses issue, as well as supervising content. In practice, the military and other departments often supervised the media, as well. 


\subsection{Television Business in the Reform Era}

In 1998, the financial crisis hit Asia and affected Indonesia. There was a massive capital flight abroad, and the Indonesian exchange rate dropped drastically almost to Rp.16.000 per 1 USD (Culp, Hane, and Miller, 1999). The economic crisis transformed into political chaos, forcing Soeharto to resign from his post (Ho and Yeh, 2014). After the massive protest, Soeharto declared his resignation and handed over power to the vice-president, Habibie. The new president dubbed his government the Reform Era.

In the Reform Era, the history of TV broadcasting can be divided into two important stages: The Euphoria of Reformation (1998-2002) and the Broadcasting Regulation stage, which began in 2002. In the first stage, people gained political freedom, with greater opportunity to make mass media products and with the policy of censorship removed. In this era, the government awarded five new private TV stations licenses; Metro TV (2000), Trans TV (2001), TV 7 (2001), Lativi (2002), and Global TV (1998). All private TV channels which had been established before the Act of 32/2002 on Broadcasting are often referred to as "Existing Stations/Jakarta TV stations."

Metro TV is a commercial TV owned by Surya Paloh, a press businessman, owner of Media Group. Trans TV is owned by Chaerul Tanjung, a successful entrepreneur. He also bought TV 7 from Jakob Utama, owner of the Kompas Group and changed the name of TV 7 to Trans7. The next TV station, Lativi was owned by Abdul Latief, an Indonesian conglomerate owner. Later, Abdul Latief sold Lativi to Aburizal Bakrie, the owner of ANTV. Under the new owner, Lativi was renamed as TV One, and replaced the main TV program with the news, competing with Metro TV.

Meanwhile, Global TV was given by Habibie to Global Informasi Bermutu (GIB), established by several figures from the Indonesian Muslim Intellectuals Association (ICMI) for an Islamic mission. The granting of the license appeared to be the president's effort to obtain political support from Moslems because of the strong anti-Soeharto sentiment among society. Unfortunately, a year after receiving the license, GIB were unable to operate the broadcasts. Interestingly, GIB shares were then sold to MNC Group owner, Harry Tanoesudibyo. Later, Harry Tanoesudibyo made some changes to Global TV despite violating the rules.

The broadcasting system in the Euphoria of the Reform era tended to be centralized by the owners in Jakarta for their business and political purposes. In this period there were many TV channel owners and media workers who become politicians. Hence the media became partisan. The viewers were treated as markets and political objects. In this era, censorship was removed and control over the media was minimal.

The Euphoria Reform provoked many complaints, such as the dominance of owners from Jakarta who delivered information favouring they're business and political perspectives (Hollander, D'Haenens, and Bardoel, 2009). Regions outside of Jakarta did not receive many economic and political benefits. Also, regional culture faded, replaced by the culture of Jakarta. This situation prompted a desire for better regulation, so the government issued Broadcasting Act No. 32/2002.

In 2002, the government implemented the Broadcasting Act formally, marking the Broadcasting Regulation stage. The principal objective of the Broadcasting Act was to create a diversity of ownership and diversity of broadcast content, as well as to foster economic potential across Indonesia. Since the enactment of the Broadcasting Act, the number of TV stations has increased dramatically to 1,251 across Indonesia (Kominfo, 2016) that comprise of public TV, private TV, pay TV, and community TV category.

A large number of local entrepreneurs who interested in the TV business is understandable because of the huge national advertising expenditure. Between 1992-1997 advertising expenditure continually grew by $23-29 \%$. In 1998 it fell $26.2 \%$ due to the monetary crisis but later continued to rise again. Between 1998-1999 it increased 40\%, from 1999 to 2000 grew to $23 \%$, and $2000-2001$ rose $25 \%$ (Setiyono, 2004). The increase continues until 2017 (Figure 1). 


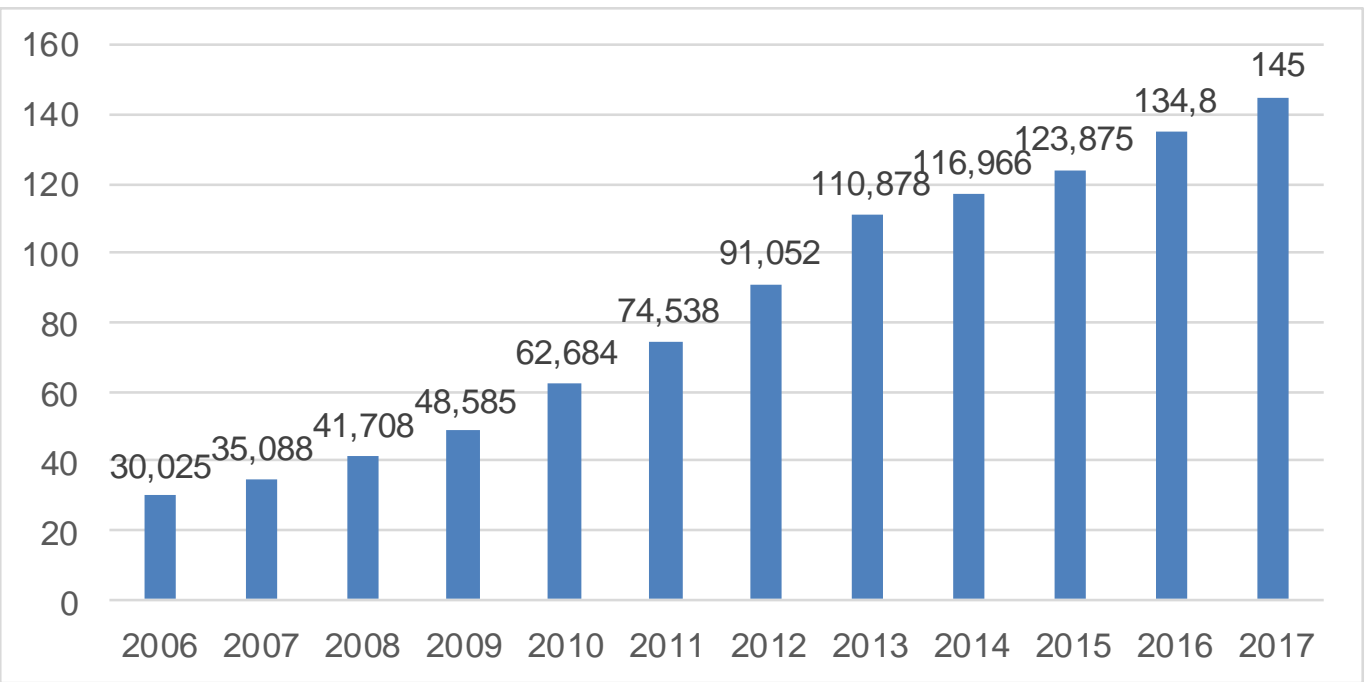

Figure 1: Indonesia advertising expenditure (in Trillions Rupiah)

Source: Gideon (2018, February); Hendriana (2015); Manan (2013); Manan (2015); Nielsen (2011); Setiyono (2004).

The TV firms from Jakarta tend to control up to $98.8 \%$ market share, while domestic TVs only got a $1.2 \%$. Business competition tends to be an oligopoly (Triwibowo and Dhewanto, 2015). There were eight firms have controlled broadcasting, namely MNC, Viva Media Asia, EMTEK, CT Corp, Indigo Multimedia, KKG, Media Indonesia, and Rajawali Citra (Table 1).

Table 1: The National TV Broadcasting Network

\begin{tabular}{|c|c|c|c|c|}
\hline No & Name of TV Broadcaster & $\begin{array}{l}\text { Established } \\
\text { on }\end{array}$ & $\begin{array}{l}\text { Coverage of } \\
\text { broadcasting }\end{array}$ & The Owner \\
\hline 1. & MNCTV (previously/TPI & 1991 & $94.11 \%$ & MNC \\
\hline 2. & RCTI & 1989 & $91.17 \%$ & MNC \\
\hline 3. & Global TV & 1998 & $85.29 \%$ & MNC \\
\hline 4. & $\begin{array}{ll}\text { iNews } & \text { (previously } \\
\text { SunTV/Sindo TV) } & \end{array}$ & 2007 & $79.41 \%$ & MNC \\
\hline 5. & ANTV & 1993 & $88.23 \%$ & Viva Media Asia \\
\hline 6. & TV One (previously Lativi) & 2002 & $88.23 \%$ & Viva Media Asia \\
\hline 7. & SCTV & 1990 & $82.35 \%$ & EMTEK \\
\hline 8. & Indosiar & 1995 & $67.64 \%$ & EMTEK \\
\hline 9. & Trans 7 (previously TV7) & 2001 & $88.23 \%$ & CT Corp \\
\hline 10. & Trans TV & 2001 & $85.29 \%$ & CT Corp \\
\hline 11. & $\begin{array}{ll}\text { NET TV } & \text { (previously } \\
\text { Spacetoon) } & \end{array}$ & 2013 & $64.70 \%$ & $\begin{array}{l}\text { Indigo } \\
\text { Multimedia }\end{array}$ \\
\hline 12. & Kompas TV & 2011 & $85.29 \%$ & KKG \\
\hline 13. & Metro TV & 1999 & $85.29 \%$ & Media Indonesia \\
\hline 14. & R TV (previously B Channel) & 2009 & $82.35 \%$ & $\begin{array}{l}\text { Rajawali } \\
\text { Corpora }\end{array}$ \\
\hline
\end{tabular}

Source: Author's calculations, based on Kominfo data, 2016

Based on the rules, the government limited the broadcasting coverage in the local area, except through networking. Consequently, the relay stations belonging to national TV had to 
be separated into different entities from the holding company. In practice, however, the local TV stations remained as part of the network. The Broadcasting Act was implemented less consistently because the government issued PP 50 of 2005 granting privileges to existing TV stations regarding ownership and broadcast coverage. They has broader coverage. Hence, the advertiser tends to choose them than local TV station. The average Jakarta TV firms receive $67 \%$ national advertising expenditure per year (Rianto and Poerwaningtias, 2013). This situation makes local TV hard to compete because generally, they can only fund $40 \%$ of operational costs (Surokim and Wahyudi, 2013).

TV broadcasting supervision is conducted by the Indonesia Broadcasting Commission, but the issuing of permits is still in the hands of the government whose implementation involves many calculations and a great deal of political lobbying.

Based on the above description, the differences in the television industry in the three governance eras in Indonesia can be explained in the following table:

Table 2: The Comparison of Broadcasting Business in The Old Order, New Order, and Reform Era of Indonesia

\begin{tabular}{|c|c|c|c|}
\hline \multirow[t]{2}{*}{ Category } & \multicolumn{3}{|c|}{ Period of regimes } \\
\hline & Old Order & New Order & Reform Era \\
\hline $\begin{array}{l}\text { Broadcasting } \\
\text { system }\end{array}$ & $\begin{array}{l}\text { Centralistic, } \\
\text { monopoly }\end{array}$ & Centralistic, nepotism & $\begin{array}{l}\text { Decentralism, some nepotism } \\
\text { but mostly market competition }\end{array}$ \\
\hline Ownership & $\begin{array}{l}\text { Public TV: } \\
\text { State-owned }\end{array}$ & $\begin{array}{l}\text { Public TV: State-owned } \\
\text { limitation; Commercial } \\
\text { TV: Elite and crony } \\
\text { limitation }\end{array}$ & $\begin{array}{l}\text { Public TV: State-owned } \\
\text { limitation; Commercial TV: } \\
\text { business people; Commercial } \\
\text { TV: Community-owned }\end{array}$ \\
\hline $\begin{array}{l}\text { Institutional } \\
\text { category of } \\
\text { broadcasting }\end{array}$ & Public TV & $\begin{array}{l}\text { Public TV, Commercial } \\
\text { TV, Subscription TV }\end{array}$ & $\begin{array}{l}\text { Public TV; Commercial TV; } \\
\text { Subscription TV; Commercial } \\
\text { TV }\end{array}$ \\
\hline Purposes & $\begin{array}{l}\text { Political } \\
\text { purposes } \\
\text { (embedding of } \\
\text { ideology, } \\
\text { building political } \\
\text { support), public } \\
\text { relations, } \\
\text { information } \\
\text { dissemination }\end{array}$ & $\begin{array}{l}\text { Public TV: embedding of } \\
\text { ideology, gaining } \\
\text { political support, } \\
\text { information } \\
\text { dissemination; } \\
\text { Commercial TV \& } \\
\text { Specific TV: profit } \\
\text { orientation }\end{array}$ & $\begin{array}{l}\text { Public TV: embedding of } \\
\text { ideology, building political } \\
\text { support, information } \\
\text { dissemination; Commercial TV } \\
\text { \& Subscription TV: profit } \\
\text { orientation; Community TV: } \\
\text { Information dissemination, } \\
\text { communication, \& social } \\
\text { integration }\end{array}$ \\
\hline Funding & $\begin{array}{l}\text { Government } \\
\text { subsidies, } \\
\text { license fees, } \\
\text { and TV } \\
\text { advertising }\end{array}$ & $\begin{array}{l}\text { Public TV: state funding, } \\
\text { other legal funding; } \\
\text { Commercial TV \& } \\
\text { subscription TV: TV } \\
\text { advertising \& other legal } \\
\text { income }\end{array}$ & $\begin{array}{l}\text { Public TV: State funding \& } \\
\text { other legal income; Commercial } \\
\text { TV: commercials \& other legal } \\
\text { income; Subscription TV: TV } \\
\text { Advertising \& subscription fees; } \\
\text { Community TV: community } \\
\text { license fees \& voluntary } \\
\text { donations }\end{array}$ \\
\hline Coverage & Nationwide & Nationwide & $\begin{array}{l}\text { Local coverage and nationwide, } \\
\text { based on networking }\end{array}$ \\
\hline $\begin{array}{l}\text { Control \& } \\
\text { supervision }\end{array}$ & Government & Government & $\begin{array}{l}\text { Indonesia Broadcasting } \\
\text { Commission }\end{array}$ \\
\hline $\begin{array}{l}\text { Licensing } \\
\text { authority }\end{array}$ & Government & Government & Government \\
\hline
\end{tabular}




\begin{tabular}{|c|c|c|c|}
\hline \multirow[t]{2}{*}{ Category } & \multicolumn{3}{|c|}{ Period of regimes } \\
\hline & Old Order & New Order & Reform Era \\
\hline $\begin{array}{l}\text { Freedom of } \\
\text { the press }\end{array}$ & $\begin{array}{l}\text { Limited } \\
\text { freedom }\end{array}$ & $\begin{array}{l}\text { Limited freedom, } \\
\text { applied revocation of } \\
\text { license, state } \\
\text { censorship }\end{array}$ & $\begin{array}{l}\text { Has freedom, self-censorship, } \\
\text { in some cases mass pressure } \\
\text { on journalists }\end{array}$ \\
\hline $\begin{array}{l}\text { The trend of } \\
\text { media } \\
\text { content }\end{array}$ & $\begin{array}{l}\text { Mostly } \\
\text { government, } \\
\text { political \& elite } \\
\text { activities }\end{array}$ & $\begin{array}{l}\text { Elites, public figures, } \\
\text { ceremonies, and press } \\
\text { releases }\end{array}$ & $\begin{array}{l}\text { Variety, popular issues, mass } \\
\text { concerns }\end{array}$ \\
\hline $\begin{array}{l}\text { The position } \\
\text { of viewers }\end{array}$ & $\begin{array}{l}\text { Viewers as an } \\
\text { object \& } \\
\text { political } \\
\text { constituent }\end{array}$ & $\begin{array}{l}\text { Viewers as a political } \\
\text { constituent and the } \\
\text { market }\end{array}$ & $\begin{array}{l}\text { Viewers as a political } \\
\text { constituent and the market }\end{array}$ \\
\hline
\end{tabular}

Source: Author's own calculations

\section{Conclusion}

The TV business in all periods of Indonesian regime has a substantial political and economic significance. As a business, TV broadcasting began to evolve in the New Order era and progressed rapidly in the Reform Era. In these two periods, the private sector puts business profit as a priority, but in the Reform period, TV business owners tend to be political players. In all eras, the public tends to be just a market.

In the Old Order, government positions were more dominant, but in the New Order and the Reform Era, the government has tended to accommodate the interests of entrepreneurs. However, no lunch is free, because the government enjoys the advantages of a media which support its power. In other words, businesspeople and the state tend to take advantage of each other. In this context, ultimately the public interest goes unnoticed.

The regulation of the TV industry in all periods has varied, following the political situation at that time. There have been similarities in licensing issues. Governments in all periods have sought to gain political advantage in the broadcasting system which has developed. All Indonesian governments tend to be less assertive in applying broadcasting regulations to all stakeholders. They tend to accommodate TV owners and broadcasters.

Evidence of practical compromises can also be seen in the granting of licenses to private parties in the New Order. Although national broadcasting is the preserve of public TV, the government allows private TV to broadcast nationwide. In the Reform Era, there have also been many practical compromises in the adoption of TV broadcasting regulations. Different treatments regarding licensing procedures, shareholding, and broadcast coverage are evidence of these accommodative methods.

A study focusing on TV business in Indonesia from an economic perspective conducted by Indonesian researchers and academics is rare. Limited data is a significant obstacle because of difficult access to company business. Unfortunately, the government also has limited data. The government does not yet have regulations that require all TV broadcasting companies to open access data to the public. Public access is still limited to companies listed in the stock market, as it is mandatory to make periodic reports. Therefore, business data in this study is still limited to companies that go-public.

\section{References}

Alimuddin, A. 2017. Growth of the Mass Media Industry in Indonesia, International Journal of Business and Management, 1(2), pp. 14-17. 
Armando, A. 2011. Televisi Jakarta di atas Indonesia: Kisah Kegagalan Sistem Televisi Berjaringan Di Indonesia. [Jakarta Television Above Indonesia: The Failure Story of Networked Television Systems in Indonesia], $1^{\text {st }}$ st Ed., Yogyakarta: Bentang Pustaka.

BPS 2010. Penduduk Berumur 15 Tahun Keatas Menurut Kelompok Umur dan Lapangan Pekerjaan Utama - Indonesia. [Population Aged 15 Years and Over by Age Group and Main Employment Field - Indonesia]. Jakarta: Biro Pusat Statistik.

Culp, C. L., Hane, S. H., and Miller, M. H. 1999. The Case for an Indonesian Corporate Finance. Journal of Applied Corporate Finance, 11(4), pp. 36-43. doi: 10.1002/erv.593

Fischer, H. D. 1976. A Conceptual Overview of World Journalism, International and Intercultural Communication,. $2^{\text {nd }}$ Ed., New York: Hastings House, p. 524.

Gideon, A. 2018. Belanja Iklan 2017 Mencapai Rp. 145 Trilyun, Terbesar Masih Televisi. [Ad Spending in 2017 Reaches Rp 145 Trillion, The Biggest Still Television]. Liputan6. Available at: http://bisnis.liputan6.com. [2 February 2018].

Global Forum on Competition. 2013. Competition Issues in Television and Broadcasting 1-9. doi:10.1177/152700250200300103

Hendriana, E. 2015. Ekonomi Kreatif: Kekuatan Indonesia Baru Menuju 2015. [Creative Economy: Indonesia's New Strength Towards 2025]. Jakarta: The Republic of Solutions.

Ho, T.K., and Yeh, K.-C. 2014. The Post-Asean Crisis Drop in Investment: The cases of Indonesia, Korea, Malaysia, and Thailand. Contemporary Economic Policy, 32(2), pp. 618-638.

Hollander, E., D'Haenens, L., and Bardoel, J. 2009. Television Performance in Indonesia 2006 Steering Between Politics, Civil Society, and Market, Asian Journal of Communication, 19(1), pp. 39-58.

Kominfo 2016. The List of Indonesia TV stations. Jakarta.

Manan, A. 2013. Potret Pers Jakarta. [Press Portrait of Jakarta]. Jakarta: Aliansi Jurnalis Independen.

Manan, A. 2015. Di Bawah Bayang-Bayang Krisis. [Under the Shadow of Crisis]. Jakarta: Aliansi Jurnalis Independen.

Marketline, 2017. Broadcasting \& Cable TV in the United States. Washington DC MIB. 2017. Annual Report 1916/17. New Delhi.

Nielsen. 2011. Belanja Iklan Media Naik 23\% [Ad Expenditure increasing 23\%]. Nielsen Newsletter. $3^{\text {rd }}$ Ed., The Nielsen Company.

Oxford Economics. 2016. The Economic Contribution of The Film and Television Industries in China. Oxford.

Panjaitan, E. L. 2006. Matinya Rating TV [The end of TV ratings]. Yogyakarta: Yayasan Obor Indonesia.

Porto, M. 2007. 'TV News and Political Change in Brazil: The impact of Democratization on TV Globo's journalism,' Journalism, 8(4), pp. 363-384.

PWC. 2016. China Entertainment and Media Outlook 2016-2020.

Rakhmani, I. 2013. Regime and Representation: Islam in Indonesian Television, 1962 to 1998, RIMA: Review of Indonesian and Malaysian Affairs.

Rianto, P., and Poerwaningtias, I. 2013. TV publik dan lokalitas budaya: Urgensinya di tengah dominasi TV swasta Jakarta,' [Public TV and cultural locality: The urgency in the middle of Jakarta's private TV dominance]. Jurnal Komunikasi, 7(2), pp. 163-176.

Setiyono, B. 2004. Cakap Kecap (1972-2003) [Skilled Word (1972-2003]. $1^{\text {st }}$ Ed., Yogyakarta: Galang Press \& Indonesian Advertising Agency Association.

Sen, K., and Hill, D. T. 2006. Media, Culture and Politics in Indonesia. $2^{\text {nd }}$ Ed., Equinox Publishing.

Sudibyo, A., and Patria, N. 2013. 'The Television Industry in Post-Authoritarian Indonesia,' Journal of Contemporary Asia, 43(2), pp. 257-275. 
Surokim and Wahyudi, M. 2013. Televisi Lokal, Strategi Jitu Memenangkan Persaingan \& Merebut Pemirsa TV pemira TV. [Local Television, Strategy to Win the Competition \& Seize TV Viewers TV Viewers]. 1st Ed., Bangkalan: UTM Press.

Triwibowo, E. and Dhewanto, W. 2015. Ekonomi Kreatif: Kekuatan baru Indonesia menuju 2025. [Creative Economy: Indonesia's new power towards 2025]. $1^{\text {st }}$ Ed., Republik Solusi. Jakarta: Republik Solusi.

Woods \& Poole Economics 2015. Local Broadcasting: An engine for Economic Growth. Washington DC.

\section{Bio-note}

Rendra Widyatama, S.I.P., MSi, is a Ph.D. student in the Business and Management, University of Debrecen, Hungary. He has the membership of the several Professional associations, such as Association of Indonesian Communication Scholars (ISKI), Association of Communication Sciences of Islamic Higher Education (ASIKOPTI), The Association of Indonesian Private Universities (APTISI). As a lecturer and Ph.D. student, the author focuses on the field of television, marketing communication, advertisement, and gender studies. 